\title{
The Implementation of Daily Journal Writing in Teaching Recount Text for the Second Grade Students in MTs Khoirotul Islamiyah Pematangsiantar
}

\author{
Marhaeni KD Matondang \\ Universitas Simalungun (USI), Siantar, Indonesia \\ MarhaeniKD@gmail.com
}

\begin{abstract}
This research is focused on the advantage of using daily journal writing in teaching recount texts for the second grade students at MTs Khoirotul Islamiyah Pematangsiantar. The problem of this research are: 1) How is the implementation of daily journal writing in teaching recount text for the second grade students at MTs Khoirotul Islamiyah Pematangsiantar? ; 2) What are the advantages of daily journal writing in teaching recount text for the second grade students at MTs Khoirotul Islamiyah Pematangsiantar?. The objective of this study are: 1) To describe the implementation of daily journal writing to teach recount text for second grade at MTs Khoirotul Islamiyah Pematangsiantar; 2) To know what are the advantages of daily journal writing in teaching recount text of second grade at MTs Khoirotul Islamiyah Pematangsiantar. From the data analysis it can be concluded that : 1) Daily journal writing makes the students motivated and interested in making recount text; 2) Using daily journal writing in teaching recount text have many advantages for the teacher and students in learning activities, it is known from the result of obsevation in the classroom, questionnaire, and interview to the English teacher.
\end{abstract}

Keywords

advantages, recount text; joumal writing, teaching

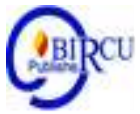

\section{Introduction}

In Indonesia, English is one of the important subjects. It has been taught since elementary school up to university level. In learning English, students need to comprehend all the things that they have received. For Indonesian students, understanding English is not easy because it is different from their native language. The differences are found in the system of sound, vocabulary and structure. These differences may bring some problems in learning language and will influence the. Students' acquisition in mastering English. The objective of English instruction is to develop students' communicative competence.

When we learn a second language, we learn to communicate with other people, with their language. To understand their language, we talk with them, read what they write their language. The fact that people frequently have to communicate with each other in writing is one of the reasons to master writing skill. Writing is a kind of expression media and a mean of communication. That is why writing is very essential to be learned by student to make good relationship with other people. There are many kinds of writing activity that we do, for example final paper, research paper, poetry, short or long story, passage or short massage and recount text. 
This study uses daily journal writing in teaching recount text, because students have adequate vocabulary, and reflect on their idea, by daily journal writing students will find it easier to write. Anything written by human beings is creative to some extent.

Based on the interview with the English teacher at MTs Khoirotul Islamiyah Pematangsiantar, the writer identifies the problems faced by the students related with writing skill. The difficulty faced by the students can be seen in writing a simple paragraph; firstly the students get difficulty in exploring their ideas into words. Secondly in writing simple paragraph students often chooses inappropriate words. In other words, the students haven't used the right diction. Thirdly the students can't make a good word order in simple sentences yet. Finally, the students have low vocabulary mastery.

Based on phenomenon, the writer chooses MTs Khoirotul Islamiyah Pematangsiantar, as a subject to do this research because in this school she found an interesting problem especially in writing. The researcher found information from the English teacher that the teacher has implemented daily journal writing for students' writing activity. The researcher will investigate the second grade students of MTs Khoirotul Islamiyah Pematangsiantar,to know the advantages and the process of learning activity in writing class using daily journal writing as a technique in teaching recount texts.

\section{Review of Literatures}

\subsection{Learning English}

According to Brown (1985), learning has many definitions, such as:

1. Acquisition or getting.

2. Retention of information or skill.

3. Retention implies storage system, memory, cognitive organization.

4. Learning involves active, conscious focus on and acting upon events outside or inside the organism.

5. Learning is relatively permanent but subject to forgetting.

6. Learning involves some form of practice, perhaps reinforced practice.

7. A change of behavior.

Syahrin (2018) states that Language is a medium of communication between humans. Language is needed by humans because human language can find their needs by communicating. As members of the community who are active in everyday life, people are very dependent on the use of language. Language learning is very important. It is used in daily activities, especially for communication.

Language plays an important role in human life. Humans use language as a means to communicate. Language is related to the principle of politeness of language which is mentioned the maxims of wisdom, generosity, appreciation, simplicity, consensus and conclusions (Darwis, 2018). The ability is the most important thing in this world. From this ability, learner can learn, practice, and understand the lesson. Learning is also the key of education. English is considered a symbol of modernization, a key to expand functional roles. It is also believed that English contributes to another type of transmutation: it internationalizes one's outlook. In learning English, students need to comprehend all the things that they have received. Parrott says, comprehension involves extracting meaning from a text, from participating in a conversation or from listening to a person or people speaking. The kinds of meaning which are extracted, and the ways in which they are extracted will depend on the purposes which underlie the reading, interacting or listening. 
Beliefs, goals, and expectations for success and failure can enhance or interfere with the learner's quality of thinking and information processing. Students' beliefs have a marked influence on their motivation. Positive emotions, such as curiosity, generally improve motivation and facilitate learning and performance.

By learning English, learners will get some advantages there are learner can interactive with other people with their language by use English language. Learning also needs motivation because motivation will drive learner to do something better. Motivation as psychological aspect takes an important part and is influential for the learner. Therefore, learners must have motivation, goal and interest in learning process.

\subsection{Writing Skill}

Writing is one of the four language skills that should be mastered in learning English. It belongs to productive skills besides speaking, in which the language users require the ability to produce language both spoken and written. There are several definitions of writing stated by some experts. The first definition is stated by Byrne that writing is an act of forming graphic symbols, or making marks on flat surface of some kind. Graphic symbols here include letters or combinations of letters that relate to the sound people make when they speak. The symbols have to be arranged, according to certain conventions, to form words, sentences, and/or paragraph.

In line with Byrne, there is also definition of writing from wikipedia.com. Writing is the representation of language in a textual medium through the use of a set of signs or symbols (known as a writing system). It is distinguished from illustration, such as cave drawing and painting, and the recording of language via a non-textual medium such as magnetic tape audio.

Writing encourages thinking and learning for it motivates communication and makes thought available for reflection. When thought is written down, ideas can be examined, reconsidered, added to, rearranged, and changed. Writing is most likely to encourage thinking and learning when students view writing as a process. Students' writing ability refers to the students' competence in applying the components of writing including content, organization, vocabulary, language use (grammar), and mechanism.

\subsection{Recount Text}

\section{a. The definition of recount text}

Recount text is a text that tells us about a past of experience. The purpose of the text to tell reader what happened in the past though a sequence of events (in order in which the events occurred).

\section{b. Generic Structure of Recount Text}

There are three generic structures of recount texts, namely, orientation, series of event, and reorientation. First, orientation is an introduction of events or experiences. It provides basic information about the story such as who was involved, what happened, where this event took place and when it happened so readers or audiences understand the text easily. In addition, setting and characters are introduced.

Second, series of events are called as a body of text. The series of events are usually written in chronological order or sequence. This stage includes how problems deal with, how character within the text feel about the events, and how the event told in detail.

Third, reorientation is stating a personal comment of the writer to the story or concluding the texts. In this stage, the writer summarizes the event but it is optional based on 
the writer. In this stage, the sequence of event is ended and any issues or problem are completely resolved by characters.

\section{c. Language Features:}

- Use of simple past tense

- Focus on temporal sequence

- Focus on specific participants

- Use of action verbs
: e.g. On Saturday I went to Surabaya

: e.g. On Monday, On Sunday

: e.g. I ( the writer)

: e.g. Went, stayed

The example of recount text:

Last Sunday, my family and I went to Ragunan zoo. It was just outside our town. When we got there, we parked our car. We walked toward the entrance gate and paid the entrance fee. Since it was so crowded, we had to stand in a long queue. Then, we continued our walk toward the animal cages. There were some beautiful tigers and big lions. They were fierce animals, so they were put in strong cages.

After that, we walked to other cages. There we saw some other animals, such as a horned rhinoceros, giraffes, and tapirs. We also saw tame animals like birds, deer, etc. finally, we had a rest and our meals on a mat under a big tree. We could feel the fresh air. We left Ragunan at $5 \mathrm{pm}$. We were tired, but we were really happy.

\subsection{Daily Journal Writing}

Language learning or experience is documented through regular, can did entries in a personal journal and then analyzed for recurring pattern or salient events. From the definition, we know that writing daily activities can be employed to monitor either the learning process or the process or both. Daily Journal kept by learners about their learning experiences can provide information and insight into language learning which is unlikely to be obtained by other means.

It appears that daily journal writing is simple but it might be effective to improve students' writing skill, for some students who do not like to write; writing daily journal writing will encourage them to write. In some cases, students do not like to write in an academic setting, but some of them like to write their personal experience. Students who do not take writing as their habit, they have some difficulties to start writing. Bell says that writing can help the writer to let the problem out, he suggests some tips to let the problem out:

a) Think about the material in advance and to begin to develop an understanding

b) Writing the material, because by writing about the material in advance, you will have a better idea of how to start.

c) Reference your journals in order to remind you of your initial thoughts.

d) Develop the framework of your first draft with only minimal cutting and pasting.

\section{Research Methods}

Research design refers to the plan or arrangement that is used to examine the question of interest. These terms tend to focus on the specific practices and options that characterize the research. In this study, researcher used qualitative-descriptive method. Because daily journal writing is already used at MTs Khoirotul Islamiyah Pematangsiantar. The writer will only do observation, interview, questioner, documentation, collecting the data.

The researcher will finds out the how the implementation of daily journal writing in teaching recount text at MTs Khoirotul Islamiyah Pematangsiantar by observation, collecting data of students at the first grade students, and the data will be analyzed as conclusion of this 
research. This research is aimed at to exploring and to describe is the advantages of daily journal writing.

The subject of this study was the second grade students of MTs Khoirotul Islamiyah Pematangsiantar The researcher observes this class because they felt difficult in writing text, especially recount text. The researcher observes the implementation of daily journal writing to see whether this technique has an advantage or not.

Then the result of questionnaire analyzed the data descriptively and using the calculation :

$$
\mathrm{P}=\frac{\mathrm{F}}{\mathrm{N}} \mathrm{X} \% 100
$$

Notes:

P: Precentage

F: Number of frequency of respondent answer

$\mathrm{N}$ Number of respondent

\section{Discussion}

The researcher had observed in the the second grade student of MTs Khoirotul Islamiyah Pematangsiantar. It was done in two meetings, on February 2020 and April 2020. During teaching learning process of daily journal writing, the researcher only observed the teacher's activity during the implementation of daily journal writing. For every meeting, the teacher gave different topic. Then the researcher describes all the activities from the first meeting until the last meeting.

Based on the interview with the English teacher, she preferred to use daily journal writing as a technique in teaching recount text in her class to improve students' interest and motivation in writing skill. The English teacher used daily journal writing because it is the easiest technique for students to be able to write well.

Based on the first observation at the second grade student of MTs Khoirotul Islamiyah Pematangsiantar, the researcher joined the class the class was very conducive because English was the first session.

Based on the researcher observation in the classroom after starting the class by praying together, the teacher greeting to the students, checked students all list, and gave motivation to the students before started. Teacher reviewed the material that she taught before. The teacher divided students into 7 groups, every group consisted 4 students. The group work made a simple paragraph about recount text with their experience in the past that related to their daily journal writing. After the teacher divided the group and every group finished their writing, the teacher asked one of student in every group to present their work. The teacher asked student to explain about recount text, the generic structure, the language features. Then teacher asked student to discuss with their friend about recount text.

After discussion, the teacher asked student to make a short paragraph individually based on their daily activities in the past by using the right generic structure, and the grammar use in recount text. During a process of making recount text with daily journal writing, the teacher wrote the difficult or unfamiliar vocabulary on the whiteboard. It also helped other students who didn't know the vocabulary. It showed that vocabulary could motivate students in their writing. This process takes a long time. The teacher gave 30 minutes to do it, after students finished the duty, the teacher asked to submit their work, because the learning ended.

Based on the implementation above, daily journal writing is used by the teacher in teaching recount text, because the teacher believes that using this technique student will 
express their ideas and find it easier to write a simple paragraph about recount text. When the time is up the teacher asks the students to submit their work.

The researcher wrote the process of teaching and learning by using daily journal writing in teaching recount text in the observation checklist. (See on appendix 1). Before the teacher implemented daily journal writing, the researcher wants to know the students response about learning English (writing) to gain data of the students' responses, the researcher used questionnaire. The result of questionnaire is showed in the following table:

Table 1. Students' Responses about their interest Learning English (Writing)

\begin{tabular}{|l|l|l|l|l|l|l|l|c|}
\hline \multirow{2}{*}{ No } & \multicolumn{2}{|c|}{ Variable } & \multicolumn{6}{c|}{ ANSWER OPTIONS } \\
\cline { 3 - 9 } & & $\mathrm{N}$ & \multicolumn{2}{|c|}{ Yes } & \multicolumn{2}{c|}{ No } & \multicolumn{2}{c|}{ Total } \\
\cline { 3 - 9 } & & $\mathrm{F}$ & $\%$ & $\mathrm{~F}$ & $\%$ & $\mathrm{~N}$ & $\%$ \\
\hline 1 & $\begin{array}{l}\text { Students interest } \\
\text { in learning English } \\
\text { especially writing } \\
\text { skill }\end{array}$ & 32 & 24 & $75 \%$ & 8 & $25 \%$ & 32 & $100 \%$ \\
\hline
\end{tabular}

From the table above, it can be seen that almost all of the students answered that they were interested in learning English especially writing. It is supported that $78 \%$ students answered they are interested in learning English. They were only $22 \%$ of students who answered that they were not interested in learning writing. The Students' interest in learn English that show by students' enthusiasm in making recount text. Based on the implementation of daily journal writing in teaching recount text, the researcher wants to know the students' response about the technique used by teacher. The researcher used questionnaire as shown in following table:

Table 2. Students' response about learning English with daily journal writing

\begin{tabular}{|l|l|l|l|l|l|l|l|l|}
\hline \multirow{2}{*}{ No } & \multicolumn{1}{|c|}{ Variable } & \multicolumn{6}{|c|}{ ANSWER OPTIONS } \\
\cline { 3 - 9 } & & $\mathrm{N}$ & \multicolumn{2}{|c|}{ Yes } & \multicolumn{2}{c|}{ No } & \multicolumn{2}{c|}{ Total } \\
\cline { 3 - 9 } & & \multicolumn{2}{|c|}{$\mathrm{F}$} & $\%$ & $\mathrm{~F}$ & $\%$ & $\mathrm{~N}$ & $\%$ \\
\hline 1 & $\begin{array}{l}\text { Students like using } \\
\text { Daily journal } \\
\text { writing in learning } \\
\text { English }\end{array}$ & 32 & 24 & $75 \%$ & 8 & $25 \%$ & 32 & $100 \%$ \\
\hline
\end{tabular}

From the table above, almost all of students answer that they like using daily activities in learning English which is $75 \%$ students like this technique. There are only $25 \%$ students answered that they do not like using daily journal writing in learning English.

Actually, the students' of grade $\mathrm{X}$ did not know how to use daily journal writing in learning recount text. However the teacher explained that the daily journal writing is used in teaching recount text. Basically, these activities were not new for them. Sometime the teacher did this technique in the speaking skill. Therefore, the material used by the teacher should be interesting. It is supported by students through questionnaire as shows below:

Table 3. Students' Opinion about the Topic

\begin{tabular}{|l|l|l|l|l|l|l|l|l|}
\hline \multirow{2}{*}{ No } & Variable & \multicolumn{8}{|c|}{ ANSWER OPTIONS } \\
\cline { 3 - 9 } & & \multirow{2}{*}{$\mathrm{N}$} & \multicolumn{2}{|c|}{ Yes } & \multicolumn{2}{c|}{ No } & \multicolumn{2}{c|}{ Total } \\
\cline { 3 - 9 } & & & $\mathrm{F}$ & $\%$ & $\mathrm{~F}$ & $\%$ & $\mathrm{~N}$ & $\%$ \\
\hline 1 & The topic is & 32 & 26 & $81 \%$ & 6 & $19 \%$ & 32 & $100 \%$ \\
\hline
\end{tabular}




\begin{tabular}{|c|c|c|c|c|c|c|c|c|}
\hline & $\begin{array}{l}\text { interesting } \\
\text { for } \\
\text { students }\end{array}$ & & & & & & & \\
\hline 2 & $\begin{array}{l}\text { It is easy for } \\
\text { students } \\
\text { to find the } \\
\text { vocabulary } \\
\text { in writing }\end{array}$ & 32 & 24 & $75 \%$ & 8 & $25 \%$ & 32 & $100 \%$ \\
\hline
\end{tabular}

From the table above, it can be seen that $81 \%$ of students are very interested in the topics used in daily journal writing. 19\% of the students say that they are not interested in the topics. Moreover, there are $75 \%$ of students saying that they feel easy to find the vocabulary when writing a daily journal. And $25 \%$ students answered that they felt difficult to find the vocabulary. The students of grade $\mathrm{X}$ don't have any difficulties in daily journal writing. It is supported by students answered through questionnaire below:

Table 4. Students' difficulties in writing a daily journal

\begin{tabular}{|l|l|l|l|l|l|l|l|c|}
\hline \multirow{2}{*}{ No } & \multicolumn{1}{|c|}{ Variable } & \multicolumn{6}{c|}{ ANSWER OPTIONS } \\
\cline { 3 - 9 } & & $\mathrm{N}$ & \multicolumn{2}{c|}{ Yes } & \multicolumn{2}{c|}{ No } & \multicolumn{2}{c|}{ Total } \\
\cline { 3 - 9 } & & & $\mathrm{F}$ & $\%$ & $\mathrm{~F}$ & $\%$ & $\mathrm{~N}$ & $\%$ \\
\hline $\begin{array}{l}\text { Students felt difficult } \\
\text { in writing a daily } \\
\text { journal that was used } \\
\text { by the teacher in } \\
\text { teaching recount text }\end{array}$ & $\begin{array}{l}\text { Students felt difficult } \\
\text { before the teacher } \\
\text { implemented daily } \\
\text { journal writing in } \\
\text { learning }\end{array}$ & 32 & 30 & $93 \%$ & 3 & $91 \%$ & 32 & $100 \%$ \\
\hline
\end{tabular}

From the table above, students who felt difficult in writing a daily journal was only $9 \%$, whereas the students felt easy to write a daily journal, it is proved $91 \%$ them answered the questioner said that they felt easy in writing a daily journal that was used by the teacher in teaching recount text. $93 \%$ of the students said that they have difficulties before the teacher used daily journal writing in teaching and learning process and $7 \%$ of the students did not felt difficult before the teacher used daily journal writing in teaching and learning activity. It is caused by the students who lack of exercise to write. They felt easy to write a daily journal because using daily journal writing students can improve their writing especially in recount text.

Based on the interview with the English teacher, she said that the students felt difficult before she used daily journal writing, because students have difficult to arrange the word to paragraph. They felt easy to write using daily journal writing because the students have enough vocabulary, reflect on their personal experience. Therefore, the students could be motivated and be active in learning English.

The obvious advantages of using daily journal writing are: first, it helps students remember their experience and helps students to recapture the moment so that the students may look at it more deeply. Second, daily journal writing stimulates the students' thought, their feelings and their actions in different way. Third, thinking in daily journal writing also allows students to clear their minds. Fourth, daily journal writing is part of students' routine 
meaning that students actually take time out to reflect on what might be happening in their practice and in their life generally. In addition, daily journal writing holds the possibility of deepening their understanding and, to making added sense of students' lives. It can also help the students to entertain, contain and channel troubling emotion. And it may also develop a greater awareness of daily life, become more alive to what is happening in daily life.

Based on the interview with English teacher, she said that the students are:

Table 5. Interview Result

\begin{tabular}{|c|c|c|c|c|c|c|c|c|}
\hline $\begin{array}{l}\text { more interesting in } \\
\text { learning when using } \\
\text { daily journal writing } \\
\text { in learning recount } \\
\text { text and motivate the } \\
\text { students in writing } \\
\text { subject, actually } \\
\text { many advantages of } \\
\text { using daily activities } \\
\text { writing. The teacher } \\
\text { doesn't have any } \\
\text { difficulties in using } \\
\text { daily journal writing. } \\
\text { Daily journal writing } \\
\text { can make the teacher } \\
\text { easy to explore their } \\
\text { knowledge about } \\
\text { recount text with the } \\
\text { students. } 4\end{array}$ & $\begin{array}{l}\text { Students } \\
\text { felt easy } \\
\text { to arrange a } \\
\text { paragraph } \\
\text { with } \\
\text { their own } \\
\text { word }\end{array}$ & 32 & 30 & $94 \%$ & 2 & $6 \%$ & 3 & $100 \%$ \\
\hline
\end{tabular}

The researcher also wants to know the students' opinion about the improvement of their writing skill after the implementation of daily journal writing. To collect the data of students' opinions, the researcher used questionnaire. The result of questionnaire is showed in the following table:

Table 6. Students' Opinion about the Improvement of Their Writing Skill after Using Daily journal writing

\begin{tabular}{|c|c|c|c|c|c|c|c|c|}
\hline \multirow[t]{3}{*}{ No } & \multirow[t]{3}{*}{ Variable } & \multicolumn{7}{|c|}{ ANSWER OPTIONS } \\
\hline & & \multirow[t]{2}{*}{$\mathrm{N}$} & \multicolumn{2}{|c|}{ Yes } & \multicolumn{2}{|c|}{ No } & \multicolumn{2}{|c|}{ Total } \\
\hline & & & $\mathrm{F}$ & $\%$ & $\mathrm{~F}$ & $\%$ & $\mathrm{~N}$ & $\%$ \\
\hline 1 & $\begin{array}{l}\text { Students' writing } \\
\text { skill became } \\
\text { better after the } \\
\text { implementation } \\
\text { of daily journal } \\
\text { writing }\end{array}$ & 32 & 25 & $75 \%$ & 7 & $25 \%$ & 32 & $100 \%$ \\
\hline
\end{tabular}

From the result of the questionnaire, it can be seen that $75 \%$ of students answered that their writing skill was better after the implementation of daily journal writing. $25 \%$ of students said that their writing skill did not get better after the implementation of the 
technique. The students of this class had good intelligence but felt bored easily. So the teacher should have many strategies in learning.

Based on the interview with the English teacher, other advantages for the teacher that it is easy in teaching students about recount text that makesthe students absorb the knowledge well. It also makes the teacher motivated in teaching and learning process. Because daily journal writing also makes the students more focused on their writing that can improve their skill writing a simple paragraph.

There is an additional and very important reason like; writing helps the students learn. First, writing reinforces the grammatical structures, idioms, and vocabulary that have been taught to the students. Second, when the students write, they also have a chance to be adventurous with the language. Third, when they write, they necessarily become very involved with the new language; the effort to express ideas and the constant use the eye, hand, andbrain is a unique way to reinforce learning.

From the statement above, writing is very important to help the students in learning activities in the class especially in grammatical structure, idiom and vocabulary to explore their ideas to arrange a paragraph through daily activities writing. Therefore, the researcher used daily journal writing in teaching recount text, this technique is useful for the students to explore their mind.

From the first meeting, the students might be a little bit confused with this activity. The teacher explained in details. The students could participate in teaching learning process. At the second meeting, the teacher asked students to explain the material in teaching learning in front of the class, after the students explained another student should give some questions to their friends. The teacher's manner made students more active and the teacher asked student to write their daily activities in specific topic. They were enthusiastic to write well in the classroom.

About the students' responses in teaching recount text using daily journal

writing, that had some good respond. It is proved from the observation checklist and the students' answer through the questionnaire that had been given by the researcher. The strong responses are from the students. Daily journal writing makes the student interested in learning English, It is supported with Winda Ayu who is the student in XD. She said "I like daily journal writing in learning recount text". It was because it was for her easy tofind the vocabularies when writing a paragraph about recount text using daily journal writing.

\section{Conclusion}

Based on findings of the research, the conclusions are as follow:

The implementation of daily journal writing in teaching recount text for the first grade students of the second grade students at MTs Khoirotul Islamiyah Pematangsiantar is: The teacher asks students to explain the material in front of the class, and then other students give some question if they did not understand what their friend explained. Not only did he give some question, but also he can give an addition for student who explained in front of the class. It can be concluded that daily journal writing makes the students motivated and interested in making recount text.

Using daily journal writing in teaching recount text have many advantages for the teacher and students in learning activities, it is known from the result of obsevation in the classroom, questionnaire, and interview to the english teacher. Accoding to brown daily jounal writing that can encourage them to write well. Based on the statemen above daily jornal writing in teching reccount text that have many advantages, there are:

a. Daily journal writing helped the student learn English. 
b. Students find it easier to write a daily journal.

c. This technique is effective for teaching learning English.

d. Daily journal writing makes students motivated to write more.

e. Students felt easy to arrange a paragraph with their own words.

f. Routine exercise in writing makes students focused on their writing.

g. Sharpening the memory.

\section{References}

Bartram. 1994. Correction: Management Mistake: appositive approach for language teachers. London: Language TeachingPublications.

Brown, 2000. Principles of Language Learning and Teaching, (San Francisco University.

Byrne, Don. 1997. Teaching Writing Skill. London: Longman.

Celce-Murcia, Marianne. 2001. Teaching English as Second or Foreign Language, Third Edition. USA: Thomson Learning Inc.

Chapman, Joyce. 1991. Journaling for Joy: Writing Your Way to Personal Growth and Freedom. Newcastle Publishing Company, Inc. North Hollywood: California.

Darwis, M. (2018). Politeness Language Analysis in Teenagers Reviewed from Sociolinguistics. Budapest International Research and Critics in Linguistics and Education (BirLE) Journal, 1(1): 15-22.

Genesse. 1997. Classroom-based Evaluation in Second Language Education. Cambridge: Cambridge University Press.

Guarino, Lois. 1999.Writing Your Authentic Life. Dell Publishing. New York:USA.

Harmer, Jeremy. 1988. How to Teach English. Harlow: Longman

Jacobs, H., et al. 1981. Testing ESL Writing: A Practical Approach. Rowley Mass.: Newbury House Publisher.

Jeremey, Harmer. 1998. How to teach English. Harlow: Longman.

Joko Priyana dkk. 2008. Interlanguge: English for Senior High School Students (Departemen Pendidikan Nasional.

Joko priyana,virga Renita sari, arnys Rahayu Irjayanti. 2008. Interlanguage: English for Senior High School Students X, Pusat Perbukuan Depatement Pendidikan Nasional.

Kachru, Braj. 1990. The Alchemy of English. The Spread, Functions, and Models of NonNative English. Urbana \& Chicago: University of Illinois press.

McMahan, Elizabeth, et al. 1996. Literature and the Writing Process 4th Edition. (New Jersey: Prentice Hall Inc.

Miller. 2000. Motives for Writing fifth edition(McGraw-Hill Higher Education)

Moleong. Lexy J. 1994. Metodologi Penelitian Kualitatif. PT Remaja Rosdakarya, Bandung .

Nunan, David. 1998. Language Teaching Methodology. Sydney: Prentice Hall

Nuning. 2006. Kreatif Bahasa Inggris. Viva Pakarindo.

Parrot, Marfin. 2002. Tasks for Language Teachers. United Kingdom: Cambridge University Press.

Prof. DR. Sugiyono, 2006. Metode Penelitian Pendidikan, Bandung: Alfabeta.

Raimes, 1983. Technique in Teaching Writing. Oxford: Oxford University Press.

Robert Keith Miller. 2004. Motives for Writing. McGraw-Hill Companies.

Santrock, J.W. 2001. Educational Psychology. New York: Mc. Millan Publishing Company.

Sarinten, 2001. Improving Students' Skill In Writing Narrative Text Through Picture Series (An Action Research at the Eighth Grade of SMP Negeri 1 Cawas, Klaten in the Academic Year of 2009/2010). Thesis S1 (Digilib. Sebelas Maret university, Surakarta). 
Suharsimi Arikunto. 2006. Prosedur Penelitian Suatu Pendekatan Praktek. Jakarta: Reineka Cipta.

Syahrin, A. (2018). Culture Repertoire in Expressive Written Language : Study of Hypothesis of Edward Sapir and Benyamin Lee Whorf. Budapest International Research and Critics in Linguistics and Education (BirLE) Journal, 1(1): 23-28.

Ulfah Fitri Ikayati. 2010. Teaching writing recount through daily activity. Thesis S1. Digilib. Universitas of IBN Khaldun. Bogor. 